\title{
The Impact of Technological Innovation on Industry 4.0 Implementation and Sustainability: An Empirical Study on Malaysian Small and Medium Sized Enterprises
}

\author{
Sreenivasan Jayashree ${ }^{1} \oplus$, Mohammad Nurul Hassan Reza ${ }^{1} \oplus$, Chinnasamy Agamudai Nambi Malarvizhi ${ }^{1}$, \\ Hesti Maheswari $^{2, *(\mathbb{D})}$, Zohre Hosseini ${ }^{3}$ and Azilah Kasim ${ }^{4}$ (D) \\ 1 Faculty of Management, Multimedia University, Cyberjaya 63100, Malaysia; jayashree@mmu.edu.my (S.J.); \\ hassanreza7171@gmail.com (M.N.H.R.); malarvizhi@mmu.edu.my (C.A.N.M.) \\ 2 Economic and Business Faculty, Pertamina University, South Jakarta 12220, Indonesia \\ 3 Sales and Marketing Department, Azarpakhsh Kerman Company, Kerman 63651, Iran; \\ z.hosseini@azarpakhsh.co \\ 4 Langkawi International Tourism and Hospitality Research Centre, School of Tourism, \\ Hospitality and Event Management, Universiti Utara Malaysia, Sintok 06010, Malaysia; azilah@uum.edu.my \\ * Correspondence: hesti.maheswari@universitaspertamina.ac.id
}

Citation: Jayashree, S.; Hassan Reza, M.N.; Malarvizhi, C.A.N.; Maheswari, H.; Hosseini, Z.; Kasim, A. The Impact of Technological Innovation on Industry 4.0 Implementation and Sustainability: An Empirical Study on Malaysian Small and Medium Sized Enterprises. Sustainability 2021, 13, 10115. https://doi.org/10.3390/ su131810115

Academic Editor: Grigorios

L. Kyriakopoulos

Received: 17 August 2021

Accepted: 2 September 2021

Published: 9 September 2021

Publisher's Note: MDPI stays neutral with regard to jurisdictional claims in published maps and institutional affiliations.

Copyright: (c) 2021 by the authors. Licensee MDPI, Basel, Switzerland. This article is an open access article distributed under the terms and conditions of the Creative Commons Attribution (CC BY) license (https:/ / creativecommons.org/licenses/by/ $4.0 /)$.
Abstract: Small and Medium sized Enterprises (SMEs) are the pillars on which most of the economies worldwide rest. Without the support of qualified technological innovation, it will be very difficult for SMEs' performance to improve and impossible for them to reach their sustainability goals. Small businesses should therefore be encouraged to embrace the next technological frontier, Industry 4.0 (I4.0). The main purpose of this research is to understand the relationship between the implementation of Industry 4.0 technologies and sustainability goals, along with an analysis of how innovation characteristics make implementing I4.0 easier for small businesses. To answer the research questions and analyse the high complex data, this research performed a structural equation model by using AMOS software. The results indicated that technology innovation characteristics have a positive significant effect on I4.0 implementation and sustainability goals. However, effective implementation of I4.0 mediates between the relationship of innovation characteristics and sustainability goals, except observability. The implications of this research are that SMEs should develop effective I4.0, implement it, and build innovation characteristics to reach sustainability goals.

Keywords: TBL sustainability; industry 4.0 implementation; SMEs; technology of innovation

\section{Introduction}

Technology and innovation have been important for improving companies' performance and sustainability since the dawn of the first industrial revolution [1,2]. Sustainable modes of production are good because they reduce overall waste in what is put in as well as in what comes out [3]. Businesses' involvement in achieving sustainability and explaining its importance is very important because they play a leading role in the global economy [4]. Striving for sustainability goals can confer competitive advantages and businesses can measure this by using the triple bottom line (TBL): social equity, ecological integrity and financial profitability [5]. It also gives firms sustainability cachet which can be used in marketing and to help customers make decisions [6]. The environmental research carried out in preparation for the achievement of sustainability goals can teach companies marketable or efficiency-enhancing new capabilities, so it's not only about saving the environment [7]. However, that remains a priority because, increasingly, company bosses are becoming aware that the erosion in natural resources will one day lead to financial losses if left unchecked [8]. Visible environmental effects raise ecological awareness among SMEs and persuade them to run environmentally friendly sustainable businesses $[9,10]$. Many of these SMEs realise that it is in their interest to run a sustainable operation, in 
order to please customers, satisfy regulators and reduce costs; ref. [11] proved that the environment and its factors have a positive influence on SME performance. However, when small businesses feel smothered by larger corporations or when SMEs feel that there are no growth opportunities in the market due to intense competition, resentment towards sustainability rules and expenses may grow $[12,13]$.

Industry 4.0 technologies can be used in all sorts of industries. However, for these new technologies to reach their full potential, they must reach small and medium-sized enterprises (SMEs), not be limited to large firms $[14,15]$. SMEs are the pillars on which most economies worldwide rest [14,15]. Industry 4.0 is full of great opportunities for SMEs. However, there are several challenges these companies must first overcome because the funds and means to carry out research and development (R\&D) are always limited for such companies $[16,17]$. To counter this problem, several European Union (EU) countries have introduced policies that foster innovation. These countries believe that such R\&D will lead to the introduction of digital technologies which will make businesses robust, more competitive and more flexible (by providing, for example, more customized products and services) but also environmentally friendly and socially conscious $[14,18,19]$.

Although the definition of Industry 4.0 has varied among practitioners and researchers, it is generally understood to be smart manufacturing through digital means [20,21]. Wide implementation implies that businesses are finding I4.0 to be beneficial [22]. In the future, reliance on I4.0 is set to soar, according to the research and advisory company Gartner and Ref. [23] identified nine pillars of I4.0. These are: "Advanced Manufacturing, Additive Manufacturing, Augmented Reality, Simulation, Horizontal/Vertical Integration, Industrial Internet, Cloud, Cyber-security and Big Data Analytics".

The increased interest by states and businesses to become environmentally sustainable has led scientists to carry out more research into how Industry 4.0 can lead to increased sustainability and how it can be implemented [24-27]. The idea is to use resources more efficiently, reduce waste and make workplaces safer and more pleasurable to be in Ref. [28]. TBL can help companies achieve this because it shifts the focus from profits at all costs (even environmental destruction) to sustainability-enhancing profit making [14].

Adopting such technologies is a challenge for any country. For emerging ones, even more so [29]. Due to the fact that so many emerging economies are still rentier states, they don't have businesses which can so easily develop or adopt such technologies [30]. Things like countries' digital, educational and economic infrastructure, as well as security and political uncertainty, also often hamper emerging economies from adopting advanced technologies [31].

Even though the benefits of smart technologies for businesses and economies are well established [32], the mechanisms by which countries can adopt Industry 4.0 technologies is not immediately apparent because the literature provides few guidelines and there is no established theoretical understanding [33]. The studies carried out so far about the relationship between Industry 4.0 technologies and sustainability have been exploratory [33,34]. Part of the problem is that practitioners and researchers have not always agreed on what constitutes Industry 4.0 technologies. As Ref. [26] point out, it is difficult to measure a technology's impact on business if you can't decide what that technology is $[24,35,36]$. The lack of agreement on certain issues has resulted in few studies being carried out on the impact of Industry 4.0 technologies on SMEs $[14,37,38]$, even though the technologies' benefits are generally accepted as being real [29].

It has been noted that many technologies that improve efficiency and performance, like energy-saving and renewable-power producing technologies, also benefit the environment [39]. They provide new knowledge, too. This knowledge can inform new environmental strategies, lead companies in new directions, make firms more flexible and make it possible to use human and other resources more wisely [40-42].

This paper's aim is to partially fill the gap of the relationship between Industry 4.0 technologies and sustainability goals. Its main focus is to see whether Industry 4.0 technologies can help companies manage economic, environmental and social assets better. 
Research on the relationship between Industry 4.0 technologies and sustainability has increased in recent years. However, findings such as Ref. [43]'s suggest that sustainability should encompass more social features along with environmental ones, and proposed that future researchers examine this gap. This research addresses that gap to give a more holistic understanding of sustainability.

Based on the above background, this study explores three main research questions, namely: (1) How do the innovation characteristics of Industry 4.0 technologies contribute to TBL sustainability and the effective implementation of those same technologies? (2) To what extent does effective implementation of Industry 4.0 affect TBL sustainability? and (3) Does the effective implementation of Industry 4.0 mediate the relationship between the innovation characteristics of these new technologies and TBL sustainability?

This paper's structure is as follows. First, there is a general introduction followed by a literature review about the relationship between Industry 4.0 technologies and sustainability. Then, the methodology of the study is explained, followed by a hypothesis test and a discussion of the results, explaining the implications for practitioners and researchers. Finally, the study's conclusions and some ideas for possible future research will be presented.

\section{Literature Review}

\subsection{Overview of Industry 4.0}

Industry 4.0's origins can be traced to the 2011 Hannover Fair. The German government made it an official strategic initiative for the manufacturing sector when it endorsed it in 2013 [44-46]. The aims of Industry 4.0 technologies are to customize and connect manufactured products to the internet; to make tracking of products and parts easier; to automate production chains and make them more flexible; to make communication between products, parts and machines the norm; to facilitate human or machine interaction (HMI); to make factories smarter with Internet of Things (IoT)-enabled products; to improve business models by adding value to the chains of production.

\subsection{Theoretical Foundation}

Industry 4.0 technologies were developed in some of the most technologically advanced countries in the world, like Germany, and work with a system of diffusion and implementation, by which the technologies become used in other countries, even developing ones [47-49]. However, when it comes to reaching emerging economies, the process tends to be slower [50-52]. One can immediately notice a big difference between the implementation rates in somewhere like Indonesia compared to Germany, for example. These differences in implementation rates can come about because of different factors, and the barriers can be several [53]. The amount of competition in the industries of suppliers and adopters can make a big difference [54]. This means that emerging countries may give a different value to Industry 4.0 technologies than advanced countries would [55,56], partly, because different countries have different needs [57].

In the past 50 years, scholars have shown great interest in the diffusion of technologies. The following are nine of the theories proposed for the differences in diffusion: the technology acceptance model (TAM) [58], the motivation model (MM) [59], the theory of planned behavior (TPB) [60], diffusion of innovations (DOI) [61], the Unified Theory of Acceptance and Use of Technology (UTAUT) technology environment organization framework (TOE) [62] and social cognitive theory (SCT) [63]. Of all these theories, DOI is the most commonly accepted theory.

The DOI theory was created by the sociologist [61]. It is largely based on the features of Industry 4.0 technologies and what the users or potential users think about such technologies. A company or organization though can have a more complex outlook on such technologies than a sole individual would. According to the DOI theory, transmitting precise and understandable information to every member in an organization are key for technology adoption success. The organization diffusion of innovation (ODI) theory posits 
that individuals think differently about an implementation process when they are part of an organization than independent. Organizations have hierarchical structures with rigid rules of communication in which individuals tend to have fixed roles. Reference [64] therefore points out that individuals in organizations think more according to their role than their independent beliefs.

In SMEs, which this study is mostly interested in, the power to make decisions about technology is concentrated in the hands of a few powerful individuals, because the founders of the company tend to be the driving force behind everything that happens. This is sometimes called authoritarian innovation. Persuading company leaders about the benefits of technology, as reference [64] points out, is a very important part of the DOI model. To do this, one needs to pay close attention to the perceived characteristics of innovation, which are: relative advantage, compatibility, complexity, trialability and observability. According to the concept of path dependencies, knowledge bases and present technological advantages lay the foundation for future technological innovations [65]. The theory that this study puts forward, therefore, is that, by uncovering the relative advantages of innovation, their compatibility, as well as their complexity, trialability and observability, SMEs could be nudged towards adopting new technologies and gaining a competitive advantage.

Without adoption of new technologies, it is impossible for businesses to reach their sustainability goals [66]. Reaching these goals is increasingly important, as evidenced by the COVID-19 crisis [67]. The role of information management from I4.0 perspective has been studied, indicating that I4.0 can undoubtedly help SMEs to achieve their sustainability goals [68]. However, due to the implementation costs, complexity, and expertise, technologies and their factors influence SMEs in both positive and negative ways [69]. Ref. [70] developed a technology-for-sustainability-adoption model based on Polish SMEs to help researchers and businesses understand the dynamics better.

\subsection{Industry 4.0 Implementation}

There are more niche areas to be explored in I4.0 implementation according to reference [65] and the researchers presented an implementation framework. This technological breakthrough shapes smart production and initiates action effectively [71] and creates core competencies for achieving sustainability [72] especially for SMEs [73]. Some industries showed rapid progress in technological implementation whereas others found it very difficult to execute new solutions [74-76]. Due to high investment cost involved in implementing new technologies, that itself acts as a barrier for SME's implementation [77]. Apart from technical challenges there are also concerns from organizations and society [78]. Technology and its progress has seen tremendous increase in efficient industry production [79] especially with I4.0 which is supported by nine technologies.

\subsection{Industry 4.0 Technologies and Triple Bottom-Line Sustainability}

Even though, as pointed out, studies are scarce, the empirical results available point toward Industry 4.0 technologies being able to improve productivity through innovative means that make modes of working more efficient [37]. Such changes have the potential to save energy, reduce emissions and avoid polluting the environment [80]. The way these positive changes to productivity and efficiency are achieved is by making changes in businesses structural [7]. However, while, on paper, the relationship between Industry 4.0 technologies and better environmental protection is evident, there is little empirical evidence that backs this up [35,81]. So far, there is in fact no clear agreement among scientists, researchers and practitioners that Industry 4.0 will lead to greater environmental sustainability [38]. The fact that some of the technologies, like 3D printing, are still in their infancy, adds to the uncertainty about their environmental credentials, even though they have been shown to benefit manufacturing $[82,83]$ suggest that, to add more certainty about the benefits of such technologies, one should use a model based on the TBL [83]. The advantage of using such a model is that it makes it easier to measure technologies' 
contributions to society and the environment. Their own studies conclude that Industry 4.0 technologies are good for both these aims, regardless of the industry a company operates in or how big it is and reference [26] reached similar conclusions about the benefits of Industry 4.0 and its contribution to environmental sustainability. Research by reference [84] also reached optimistic conclusions about Industry 4.0's contributions to environmental sustainability, particularly energy efficiency and resources. However, they also warned that more studies are needed to gauge results.

Comprehensive digitization can help companies make more effective use of these strategies because it provides real-time and precise information about the environment, according to references $[85,86]$. A study of the previous literature by reference [7] looked at different ways of addressing the issue of sustainability and Industry 4.0. It took into consideration interviews with experts in the field [27], exploratory studies [85], statistical data and other materials about waste and its effects on the environment. This literature review revealed that there are still significant challenges in implementing Industry 4.0 technologies and that more needs to be done to understand their full impact (both positive and negative) on the sustainability. New research would help scientists and practitioners better understand how Industry 4.0 technologies can contribute to the achievement of the United Nations sustainable development goals (SDGs) by improving TBL sustainability [7,39].

\section{Hypotheses Development}

\subsection{Hypotheses Development of Relative Advantage}

The phrase 'relative advantage' refers to the advantage one gets by using new technology as opposed to using what came before [87]. What innovation is sought depends on what the user wants to improve [59]. Innovations whose advantages are very clear, such as strategic effectiveness (e.g., increasing sales) and operational effectiveness (e.g., reducing costs) are more likely to be adopted [88]. Industry 4.0 technologies have so far shown that they can considerably improve processes and practices, so they have a good chance of being adopted [89]. Relative advantage has been found to play an important role in technology diffusion so this concept must be studied ever more in the context of Industry 4.0 [90-92].

Disruptions created by 4.0 technologies in relation to environmental sustainability were identified by reference [93]. Technologies like Big Data, cloud computing and the IoT, which all form part of Industry 4.0, can contribute towards controlling pollution, carbon dioxide $\left(\mathrm{CO}_{2}\right)$ emissions, and climate change, while improving water treatment and waste management, as well as more sustainable supply chains.

Chinese companies were implementing radio-frequency identification (RFID) technologies and found that relative advantage created a positive but not very significant impact [94]. A review of Big Data innovations by reference [95], meanwhile found that Big Data's ability to contribute to innovation, competition, productivity, customer value and ideal business solutions had a big impact on Big Data's implementation by several companies. In the context of environmental sustainability, this is very good because, as the empirical study by reference [96] shows, Big Data is a strong predictor of more social and environmental protection. The advantages of Big Data are so prevalent for sustainability because, Big Data can transform the way businesses operate and respond to situations. Like Big Data, cloud computing can also contribute towards reducing costs and faster performances, as well as provide important back-up options [97]. Taking all this into consideration, this paper therefore posits that relative advantage is a main factor that can persuade companies to adopt Industry 4.0 technologies, because companies adopt technologies whose benefits clearly outweigh any downsides. Industry 4.0 is associated with flexibility, higher customization and more resource efficiency, so it is in a good position for implementation by several companies and industries of all sizes.

Hypothesis 1a (H1a). There is a significant positive relationship between relative advantage and effective implementation of I4.0. 
Hypothesis $\mathbf{1 b} \mathbf{b} \mathbf{H} \mathbf{b})$. There is a significant positive relationship between relative advantage and TBL sustainability.

Hypothesis 1c (H1c). Effective implementation of I4.0 mediates the relationship between the relative advantage and TBL sustainability.

\subsection{Hypotheses Development of Complexity}

Technologies are considered to be more complex the more challenging they are to use [60]. The higher the level of complexity, the less they are likely to be adopted [98]. Lack of technical expertise often hinders SMEs from adopting Industry 4.0 technologies because of their complexity [99]. Complexity is usually measured by looking at the number of diverse relationships and the number of diverse elements. Cyber-physical systems have multiple heterogeneous specialized devices which are able to operate flexibly according to the environment they are in. They do this with the help of data analysis and applications which integrate different business functions and innovations [100]. However, for such a system to work smoothly, there should ideally be a set of protocols and communication standards that make integration across business functions easier. Making hardware and software run smoothly together can be particularly complex [16]. When there is a lot of complexity, users often feel confused and are not sure about how to use a technology. This can negatively affect the decision to adopt new technology [101]. Studies in the past have identified a strong correlation between functionality and the decision to adopt new technologies [102,103]. Attitudes of individuals towards technology are usually based on the perception of complexity $[103,104]$. For example, blockchain technology is often perceived as complex by individuals and so they find it difficult to understand and have confidence in it unless it is integrated in easier-to-use systems [105]. The transaction mechanisms of blockchain have raised concerns about their speed. Furthermore, blockchain implementation can partly be hindered by security challenges or the fact that the technology is still in its infancy [106]. When users feel that they don't have much control over the outcome of a system, they become increasingly suspicious about that system [107]. From companies' point of view, they will be less likely to adopt a new technology if they see it as very complex and incompatible with their present technologies and practices [108].

Hypothesis $\mathbf{2 a}(\mathbf{H} 2 \mathbf{a})$. There is a significant positive relationship between complexity and effective implementation of I4.0.

Hypothesis $\mathbf{2 b}(\mathbf{H} \mathbf{2 b})$. There is a significant positive relationship between complexity and TBL sustainability.

Hypothesis 2c (H2c). Effective implementation of I4.0 mediates the relationship between complexity and TBL sustainability.

\subsection{Hypotheses Development of Compatibility}

How much a new technology is compatible with existing company structures, infrastructure, procedures and values influences its likeliness of being adopted [63]. The most ideal situation is when new technologies are compatible with current technological infrastructure and work practices [109]. For SMEs, to avoid resistance from employees, it is important that changes are compatible with their culture [98]. E-businesses are technological by nature, so they have a good starting point, but they still need to find systems compatible with their organization. Old production systems and work practices can greatly hinder the implementation of Industry 4.0 technologies [110]. Without proper compatibility, there is a real risk of implementation failure [111]. The issue of the importance of compatibility has come up in several studies.

Thus, this study can conclude that if SMEs have negative feelings towards advanced technologies, they will find their implementation hard to master. If, however, Industry 4.0 is concomitant with the technology that companies already use, then its technologies 
will more likely be successful in SMEs. In a study [112] concluded that the higher the level of perceived structure compatibility, the more likely it was that advanced technologies would be adopted. An empirical study by reference [92] reached a similar conclusion about Malaysian manufacturing SMEs. The study claimed that compatibility leaves a positive impact and persuades employees to take up the use of a new technology. When the new processes fit with the old system, companies are more likely to implement a new value creation approach [89].

An empirical study was carried out to look into the implementation of additive manufacturing (AM) technology in the production of industrial parts. Similar to the other studies, they too found that the introduction of AM technology is dependent on compatibility with older systems, processes and infrastructure [79]. Study by reference [113] also confirmed the positive relationship between compatibility and the implementation of new technologies, as did reference [114], who also pointed out that Industry 4.0 technologies can introduce alternative socio-economic models in societies that adopt them widely and so change the trajectory of nations, making them more in harmony with their natural surroundings. Technologies which achieve this harmonization of man and nature are known as green, or clean, technologies. They use existing processes, applications and practices by making it better, helping society achieve sustainability goals and reduce harm to the planet. The following indicator is based on these ideas.

Hypothesis 3a (H3a). There is a significant positive relationship between compatibility and effective implementation of I4.0.

Hypothesis $\mathbf{3 b} \mathbf{\mathbf { H }} \mathbf{\mathbf { 3 }} \mathbf{b})$. There is a significant positive relationship between compatibility and TBL sustainability.

Hypothesis 3c (H3c). Effective implementation of I4.0 mediates the relationship between compatibility and TBL sustainability.

\subsection{Hypothesis Development of Trialability}

Trialability is when potential adopters feel they have the chance to experiment with a technology before adopting it full-scale [87]. Trialability reduces the anxieties of potential adopters and so is an important feature in emerging technologies [115]. For SMEs, trialability is essential because innovation funds tend to be limited and so they must know immediately whether a new technology will bring benefits [116]. Trialability can be the most important predictor of adoptability because trialability makes benefits of technology faster $[117,118]$. The faster benefits can be revealed, the faster the implementation will be [117]. Trials are good because they put potential adopters' minds at ease and show that a technology is less complex than it might seem at first [119]. Trials also make it possible to iron out issues that might make it difficult for a company to adopt a technology. [120].

The literature clearly shows that the chance to trial a technology greatly improves its likelihood of implementation. Implementation of cloud technology was studied by reference [121] and found trialability to be a major factor that affected its implementation in micro, small and medium enterprises. A study by reference [91] similarly found a clear connection between trialability and technology implementation. Studying the main factors that persuade companies to adopt Big Data technologies, and reference [95] concluded that trialability was one of the strongest factors [122]. However, in a similar study about 3Dprinting in United States manufacturing, reference [123] found more mixed results about the effects of DOI and suggested that more research is needed to confirm its effectiveness. Considering all the advantages that trialability seems to offer, BDA service providers should offer a trial version to generate higher implementation rates of their technologies among SMEs.

Hypothesis $4 \mathbf{a}(\mathbf{H} 4 \mathbf{a})$. There is a significant positive relationship between trialability and effective implementation of I4.0. 
Hypothesis $\mathbf{4 b} \mathbf{b} \mathbf{H} \mathbf{4 b})$. There is a significant positive relationship between trialability and TBL sustainability.

Hypothesis $4 \mathrm{c}(\mathbf{H} 4 \mathbf{c})$. Effective implementation of I4.0 mediates the relationship between trialability and TBL sustainability.

\subsection{Hypotheses Development of Observability}

Observability refers to how much the results of an innovation are visible to outsiders [63]. Observability is defined by reference [124] as "the process by which companies observe the success factor of other firms that have already adopted that technology". So far, studies have given inconclusive evidence about how much observability affects technology implementation rates. However, reference [125], who studied the issue, have suggested that observability is a considerable factor in implementation. There is some evidence for this because reference [126-128] tested the issue empirically and found a significant relationship between observability and technology implementation. Reference [129] also found a significant relationship in his study, which was about BDA implementation in supermarkets. However, the relationship remains controversial and has been said to be weak $[95,129]$. Although this study will remain cognizant about this controversy, observability does seem to have some positive effects, so the hypotheses being presented are:

Hypothesis 5a (H5a). There is a significant positive relationship between observability and effective implementation of I4.0.

Hypothesis $\mathbf{5 b} \mathbf{b} \mathbf{H} \mathbf{5 b})$. There is a significant positive relationship between observability and TBL sustainability.

Hypothesis $5 \mathbf{c}(\mathbf{H} 5 \mathbf{c})$. Effective implementation of I4.0 mediates the relationship between observability and TBL sustainability.

\subsection{Hypothesis: Development of Effective Implementation of I4.0 and TBL Sustainability}

The high costs of I4.0 implementation act as an investment barrier for SMEs [130]. Apart from the technical challenges of implementation, there are also concerns about how well organisations and society can engage with I4.0 [131]. Clearly, for implementation to be successful, both human and technical aspects must be addressed [132,133]. Integration of I4.0 technologies in organisations must be vertical, horizontal and end-to-end [134,135]. Vertical integration adds flexibility, agility and efficiency into a reconfigured production system by integrating several hierarchical systems in an organisation [136]. Horizontal integration is the integration of value networks into smooth cooperation in the value chain across firms and organisations [137]. End-to-end engineering makes unique creations in the value chain possible [22]. Full integration of all these aspects results in more flexibility, faster lead times and more efficient market reach [138]. The environmentally approachable technologies used across several sectors decrease cost and boost turnover [139].

Hypothesis 6 (H6): There is a significant relationship between effective implementation on I4.0 and TBL sustainability.

Relationships among variables and their direct and indirect effects are depicted clearly in Figure 1 below. 


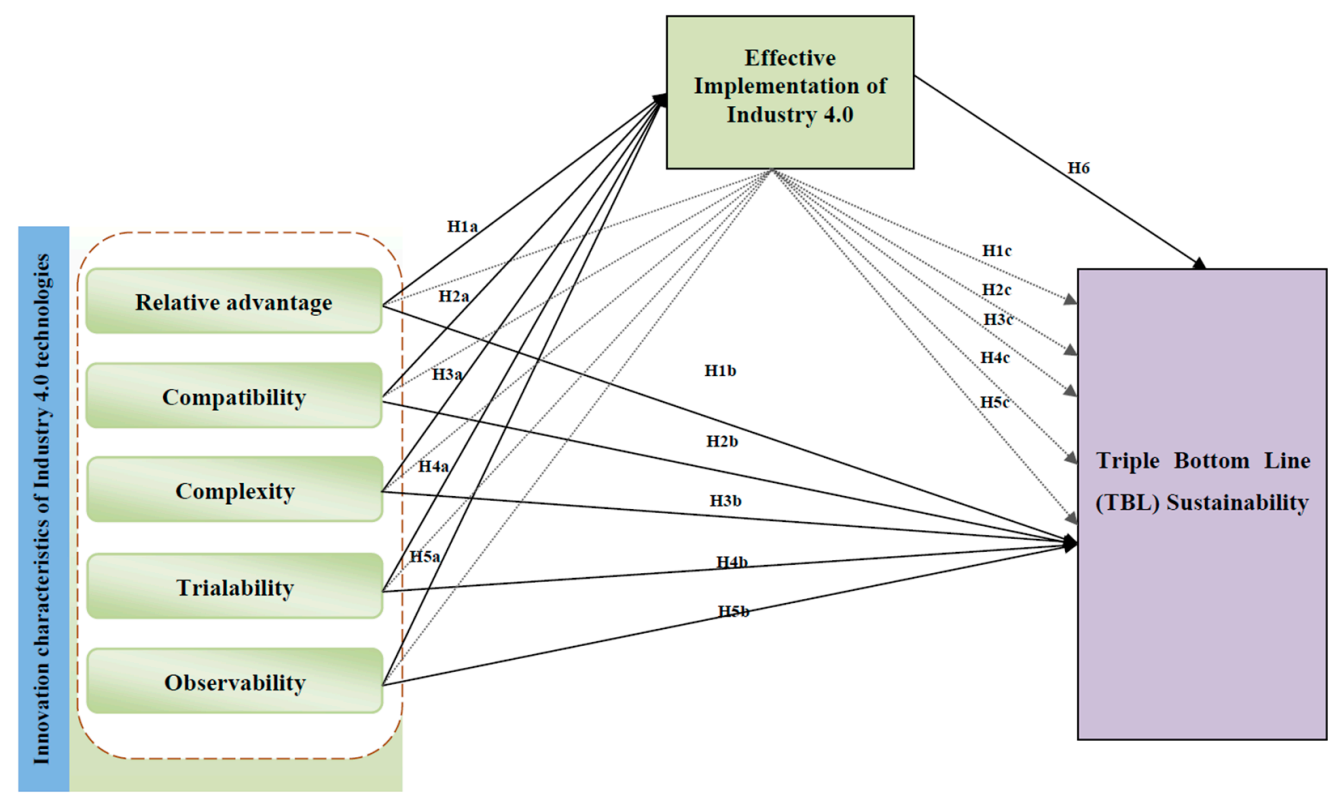

Figure 1. Conceptual Framework.

\section{Materials and Methods}

This research aims to measure the impact of innovation characteristics on effective implementation of Industry 4.0 and TBL sustainability. Diffusion of innovation variables as seen in the framework are used in this study. The research (Figure 1) shows that the innovation characteristics of Industry 4.0 technologies assisting SMEs to attain TBL sustainability through effective implementation of Industry 4.0.

\subsection{Population and Sampling}

The authors employed a cross-sectional approach and obtained quantitative data through a questionnaire-based of registered SMEs in Malaysia. The population of the study comprised of the SMEs from the Malaysian SME Business Directory SME Corp. The respondents for the study were the higher-level managers who were familiar with Industry 4.0 implementation and more familiar with their organizational practices [140].

For Structural Equation Modelling (SEM) studies, reference [141] proposed a suitable sample size of 200 as minimum and 400 as maximum. The authors used G-Power version 3.1 to determine the sample size. The study required a sample size of 255 based on a power of 0.80 with a lower effects size of 0.055 to test the model with 6 predicters. However, the authors decided to collect data from more than 300 SMEs in Malaysia to avoid any probable difficulties from a small sample size. The study adopted a simple random sampling method to identify the potential respondents for the study. The authors contacted the respondents through e-mail, phone calls, and personal visits and sent 1100 questionnaires to the SMEs' managers. In reply, 409 questionnaires were returned while 13 were incomplete and the incomplete questionnaires were excluded from the analysis. Hence, 396 responses were used for the final data analysis.

\subsection{Measurements}

The questionnaire used in the study was reliable and valid as the measurement items were taken from existing literature. The 5-point Likert scale (where 1 stands for strongly disagree and 5 for strongly agree) was employed in this study in order to make choosing options as easy as possible for the respondents. The measurement items used in the questionnaires are presented in Table 1 along with their sources. 
Table 1. Measurement item and the sources.

\begin{tabular}{|c|c|c|}
\hline Variables \& Constructs & Items & Sources \\
\hline Relative Advantage & The use of smart technologies enables our organization to: & \\
\hline RA1 & Reduce the cost. & \multirow{7}{*}[89,92]{} \\
\hline RA2 & Increase resource efficiency. & \\
\hline RA3 & Enhance energy efficiency monitoring system. & \\
\hline RA4 & Improve material usage. & \\
\hline RA5 & Build lightweight products. & \\
\hline RA6 & Produce customized products. & \\
\hline RA7 & Increase sales and revenue & \\
\hline \multicolumn{3}{|l|}{ Complexity } \\
\hline $\mathrm{CX} 1$ & Smart technologies are easy to understand. & \multirow{7}{*}[4,87,89]{} \\
\hline $\mathrm{CX} 2$ & Smart technologies are easy to implement. & \\
\hline CX3 & Using smart technologies for implementing Industry 4.0 is easy. & \\
\hline $\mathrm{CX} 4$ & Our organization has adequate infrastructural systems to implement smart technologies. & \\
\hline CX5 & Our employees have knowledge and understanding of smart technologies. & \\
\hline CX6 & Our employees do not require a lot of training to adopt smart technologies. & \\
\hline CX7 & Our organization has the technical support to implement Industry 4.0. & \\
\hline \multicolumn{3}{|l|}{ Compatibility } \\
\hline $\mathrm{CP} 1$ & Smart technologies fit our company well to implement Industry 4.0. & \multirow{5}{*}{ [92] } \\
\hline $\mathrm{CP} 2$ & The execution of smart technologies requires few firm-specific adaptations. & \\
\hline $\mathrm{CP} 3$ & We can integrate the software easily for smart technologies into our existing IT setting. & \\
\hline $\mathrm{CP} 4$ & Smart technologies are compatible with the existing values of our employees. & \\
\hline CP5 & Smart technologies are compatible with the mentality of our employees. & \\
\hline \multicolumn{3}{|l|}{ Trialability } \\
\hline TRL1 & The results of introducing smart technologies are apparent to our organization. & \multirow{5}{*}[90,142]{} \\
\hline TRL2 & Our organization had a great deal of opportunity to try various smart technologies. & \\
\hline TRL3 & Using the smart technologies provide greater control over our operational activities. & \\
\hline TRL4 & It is easy to recover from mistakes when using the smart technologies. & \\
\hline TRL5 & Ability to undo operations are adequate when using the smart technologies. & \\
\hline \multicolumn{3}{|l|}{ Observability } \\
\hline OBS1 & Our organization observes competitor's initiatives on Industry 4.0. & \multirow{5}{*}[87,90]{} \\
\hline OBS2 & Implementing smart technologies helps us to perform better than domestic competitors. & \\
\hline OBS3 & Implementing smart technologies helps us to perform better than competitors. & \\
\hline OBS4 & Our employees can easily observe others using smart technologies in the organization. & \\
\hline OBS5 & Implementing smart technologies will generate a good image of the organization. & \\
\hline \multirow{8}{*}{$\begin{array}{c}\text { Industry } 4.0 \\
\text { implementation } \\
\text { IND1 } \\
\text { IND2 } \\
\text { IND3 } \\
\text { IND4 } \\
\text { IND5 } \\
\text { IND6 } \\
\text { IND7 }\end{array}$} & While implementing Industry 4.0, our organization's technological integration. & \multirow{8}{*}{ [143] } \\
\hline & Enhances employees' innovation performance. & \\
\hline & Helps employees to manage the tools and techniques. & \\
\hline & Enables to create a variety of products. & \\
\hline & Allows to improve the product quality. & \\
\hline & Makes the inventory related information visible throughout the supply chain. & \\
\hline & Helps to maintain a smart product order management system. & \\
\hline & Assists for early market entrants. & \\
\hline TBL sustainability & The effective implementation of Industry 4.0 enables our organization to: & \multirow{8}{*}{$\begin{array}{c}{[144-} \\
147]\end{array}$} \\
\hline TBLS1 & Reduce the energy consumption. & \\
\hline TBLS2 & Reduce the air emission. & \\
\hline TBLS3 & Reduce the waste of water. & \\
\hline TBLS4 & Reduce the cost of purchasing materials. & \\
\hline TBLS5 & Increase return on financial assets. & \\
\hline TBLS6 & Increase annual sales revenue. & \\
\hline TBLS7 & Our organization focuses employee awareness on sustainability. & \\
\hline
\end{tabular}




\subsection{Methods of Analysis}

Multivariate analyses should be applied to studies that want to understand the data structure in high dimensions [148]. The multivariate analysis method is used to analyse data consisting of many variables, and it is suspected that these variables are related to each other [149]. There are three types of multivariate analyses, namely, dependency, interdependence, and structural models. The structural modelling technique is a technique that tries to analyse the relationship between dependent and independent variables simultaneously [150].

A complete SEM model basically consists of a measurement model and a structural model. Measurement models are intended to confirm a dimension or factor based on empirical indicators. Structural models are models regarding the structure of the relationship that forms or explains causality between factors. Some of the steps that must be taken to make a complete model are (a) Development of theory-based models; (b) Development of flowcharts to show causality; (c) Conversion of flowcharts into a series of structural equations and measurement model specifications; (d) Selection of input matrices and estimation techniques for the built model; (e) Assessment of identification problems; (f) Model evaluation/Goodness of Fit; (g) Interpretation and Modification of the model.

The accuracy of a model is reviewed through various goodness of fit criteria, most of which are carried out automatically by the AMOS software. Complete evaluation of the model consists of (a) Evaluation of sample size, (b) Evaluation of normality and linearity assumptions. When SEM is estimated with Maximum Likelihood by calculating the critical ratio whose value range is \pm 2.58 ; (c) Evaluation of outliers, namely data that has unique characteristics that look very different from other observations and appear in the form of extreme values for univariate outliers or multivariate outliers. The evaluation of univariate outliers is done by calculating the z-score value with a threshold in the range of \pm 3.00 while the evaluation of multivariate outliers can be analysed by looking at the rarity of an observation of the average of all variables in a multidimensional space (Mahalonobis distance) [141,151]; (d) Evaluation of assumptions on multicollinearity and singularity; (e) Evaluation of goodness of fit criteria with cut-off value is presented in Table 2 [151]; and (f) Analysis of direct effects, indirect effect, and total effect. The three valid criteria to be met to analyse the SEM path structure, namely unidimensionality (factor loading $\geq 0.50$ ), discriminant validity (correlation $\geq 0.30$ ), and internal reliability (Cronbach alpha $\geq 0.70)$ [152].

Table 2. Goodness of fit indices.

\begin{tabular}{cc}
\hline Goodness of Fit Indices & Cut-Off Value \\
\hline Chi square & Expected small \\
\hline CMIN/DF & $\leq 2.00$ \\
\hline RMSEA & $\leq 0.08$ \\
\hline GFI & $\geq 0.90$ \\
\hline AGFI & $\geq 0.90$ \\
\hline TLI & $\geq 0.95$ \\
\hline CLI & $\geq 0.95$ \\
\hline
\end{tabular}

\section{Results}

The questionnaire for this research tackled I4.0 practices among SMEs in Malaysia which was the target population and the unit of analysis was the organisation. The respondents were managers with at last three years of experience in I4.0 implementation. The list was obtained from the SME Corporation and Federation of Malaysian Manufacturing.

When conducting multivariate analyses by developing SEM, researchers need to properly address the inability of the developed model to produce good estimates. Therefore, the model must be evaluated before being used to estimate each parameter. The SEM 
model, when estimated using Maximum Likelihood Estimation, requires the fulfilment of normality assumptions that can be obtained by observing the critical ratio from the results of the assessment of normality in output AMOS program. But before that, the factor loading of each parameter and the reliability of each construct must first be ensured to meet the requirements. The loading factor value is taken from the estimation of Standardized Regression Weights, while the reliability test was carried out by using the split-half Cronbach's Alpha method [151,152]. The results are summarised in Table 3.

Table 3. Factor loading, reliability, and critical ratio.

\begin{tabular}{|c|c|c|c|c|c|}
\hline Constructs & Indicators & Factor Loading & Reliability & Critical Ratio & Results \\
\hline \multirow{7}{*}{ Relative Advantage } & RA 1 & 0.99 & \multirow{7}{*}{0.830} & -2.025 & $\mathrm{~A}$ \\
\hline & RA 2 & 0.98 & & -2.180 & A \\
\hline & RA 3 & 0.98 & & -2.110 & A \\
\hline & RA 4 & 0.82 & & -0.214 & A \\
\hline & RA 5 & 0.76 & & -2.038 & $\mathrm{~A}$ \\
\hline & RA 6 & 0.06 & & -4.438 & NA \\
\hline & RA 7 & 0.05 & & -3.197 & NA \\
\hline \multirow{7}{*}{ Complexity } & CX 1 & 0.96 & \multirow{7}{*}{0.821} & -2.396 & $\mathrm{~A}$ \\
\hline & $\mathrm{C} \times 2$ & 0.97 & & -2.312 & $\mathrm{~A}$ \\
\hline & $\mathrm{C} \times 3$ & 0.96 & & -2.221 & $\mathrm{~A}$ \\
\hline & $\mathrm{CX} 4$ & 0.74 & & -2.052 & $\mathrm{~A}$ \\
\hline & CX 5 & 0.76 & & -1.305 & $\mathrm{~A}$ \\
\hline & CX 6 & 0.47 & & -2.711 & NA \\
\hline & $\mathrm{CX} 7$ & 0.12 & & -3.033 & NA \\
\hline \multirow{5}{*}{ Compatibility } & $\mathrm{CP} 1$ & 0.91 & \multirow{5}{*}{0.954} & 1.628 & A \\
\hline & $\mathrm{CP} 2$ & 0.97 & & -2.430 & $\mathrm{~A}$ \\
\hline & $\mathrm{CP} 3$ & 0.98 & & -2.543 & A \\
\hline & $\mathrm{CP} 4$ & 0.92 & & -2.336 & $\mathrm{~A}$ \\
\hline & CP 5 & 0.85 & & -2.181 & A \\
\hline \multirow{5}{*}{ Trialability } & Trl_1 & 0.60 & \multirow{5}{*}{0.877} & -0.895 & A \\
\hline & Trl_2 & 0.97 & & -1.952 & $\mathrm{~A}$ \\
\hline & Trl_3 & 0.98 & & -0.209 & A \\
\hline & Trl_4 & 0.92 & & -2.343 & $\mathrm{~A}$ \\
\hline & Trl_5 & 0.75 & & -2.458 & A \\
\hline \multirow{5}{*}{ Observability } & OB 1 & 0.42 & \multirow{5}{*}{0.646} & -3.889 & NA \\
\hline & OB 2 & 0.14 & & -3.774 & NA \\
\hline & OB 3 & 0.98 & & -2.473 & $\mathrm{~A}$ \\
\hline & OB 4 & 0.99 & & -2.509 & $\mathrm{~A}$ \\
\hline & OB 5 & 0.98 & & -2.565 & $\mathrm{~A}$ \\
\hline \multirow{7}{*}{$\begin{array}{l}\text { Effective implementation of } \\
\text { Industrial } 4.0\end{array}$} & IND 1 & 0.59 & \multirow{7}{*}{0.771} & -2.369 & $\mathrm{~A}$ \\
\hline & IND 2 & 0.62 & & -1.775 & $\mathrm{~A}$ \\
\hline & IND 3 & 0.47 & & -4.321 & NA \\
\hline & IND 4 & 0.09 & & -3.389 & NA \\
\hline & IND 5 & 0.97 & & -0.359 & $\mathrm{~A}$ \\
\hline & IND 6 & 1.00 & & -0.357 & $\mathrm{~A}$ \\
\hline & IND 7 & 0.99 & & -0.441 & $\mathrm{~A}$ \\
\hline \multirow{7}{*}{$\begin{array}{l}\text { Triple Bottom Line } \\
\text { (Sustainability) }\end{array}$} & TBL 1 & 0.33 & \multirow{7}{*}{0.942} & -3.488 & NA \\
\hline & TBL 2 & 0.31 & & -4.421 & NA \\
\hline & TBL 3 & 0.36 & & -2.102 & $\mathrm{~A}$ \\
\hline & TBL 4 & 0.37 & & -2.153 & $\mathrm{~A}$ \\
\hline & TBL 5 & 0.95 & & -2.221 & A \\
\hline & TBL 6 & 0.98 & & -2.455 & $\mathrm{~A}$ \\
\hline & TBL 7 & 0.97 & & -2.474 & $\mathrm{~A}$ \\
\hline
\end{tabular}


There are 12 parameters that do not meet the minimum loading factor limit, namely 0.50. The produced customized products (RA_6) and increase sales and revenue (RA_7) parameters were not valid to measure the relative advantage construct. These indicators were also not normally distributed. The training (CX_6) and technical support (CX_7) parameters were not valid or normally distributed. Competitor's initiative on Industry 4.0 (OB_1) and implementing smart technologies to perform better than domestic competitors (OB_2) are unimportant to the respondents. They expected the implementation of technology to make it easier for them to work and were not keen about it adding product variety (IND_3) and improving its quality (IND_4). Therefore, these indicators could not measure the constructs and hence could not be used for the next steps. Since many parameters of the sustainability variable were not valid, this study maintained the third parameter (TBL_3) and the fourth parameter (TBL_4). This can still be tolerated if the number of research samples is very large or far above the minimum requirements [141]. In addition, the critical values of the two parameters met the requirements, so it can be concluded that both are normally distributed and feasible to be maintained.

The final stage of testing the SEM model used in the study is to calculate the number of parameters that will be compared with the cut-off value of goodness of fit as shown in Table 4. The chi square and GFI test results in marginal conditions, while others have good conditions. Therefore, the model is fit for the next steps i.e., predicting direct and indirect impact of independent variables (relative advantage, complexity, compatibility, trialability, and observability) on dependent variable (sustainability) through implementation of Industry 4.0 as mediating variables.

Table 4. Goodness of fit.

\begin{tabular}{cccc}
\hline Criteria & Cut-Off Value & Model Test Result & GOF Condition \\
\hline X $^{2}$ Chi square & The smaller the better & 793.1 & Marginal \\
Probability & $\geq 0.05$ & 0.208 & Good \\
CMIN/DF & $\leq 2.00$ & 1.673 & Good \\
RMSEA & $\leq 0.08$ & 0.059 & Good \\
GFI & $\geq 0.90$ & 0.918 & Good \\
AGFI & $\geq 0.90$ & 0.932 & Good \\
CFI & $\geq 0.90$ & 0.804 & Marginal \\
\hline
\end{tabular}

Because the developed model still has a large residual, the researchers modified the model. Modifications can be made with a fairly strong theoretical justification. If the standardised residual covariances matrix has a value outside the ring \pm 2.58 and probability $<0.05$, then the estimated model needs to be modified [152]. In addition, researchers also pay attention to the large value of the modification indices and the strongest theoretical basis. By estimating the coefficient, the chi square value will decrease, and the model improves better [149]. The best estimated value resulting from multiple modifications is shown in Figure 2.

The estimation summary is presented clearly in Table 5. Relative advantage positively and significantly affects effective implementation of I4.0. The relative advantage from using innovative information technology increases the desire of SMEs to implement I4.0 by 13\% (Hypothesis H1a) and the environmental performance by 30\% (Hypothesis H1b). These findings are in line with the research of reference [91,96,97]. Our respondents recognised that smart technology is easy to understand and support the implementation of I4.0. 


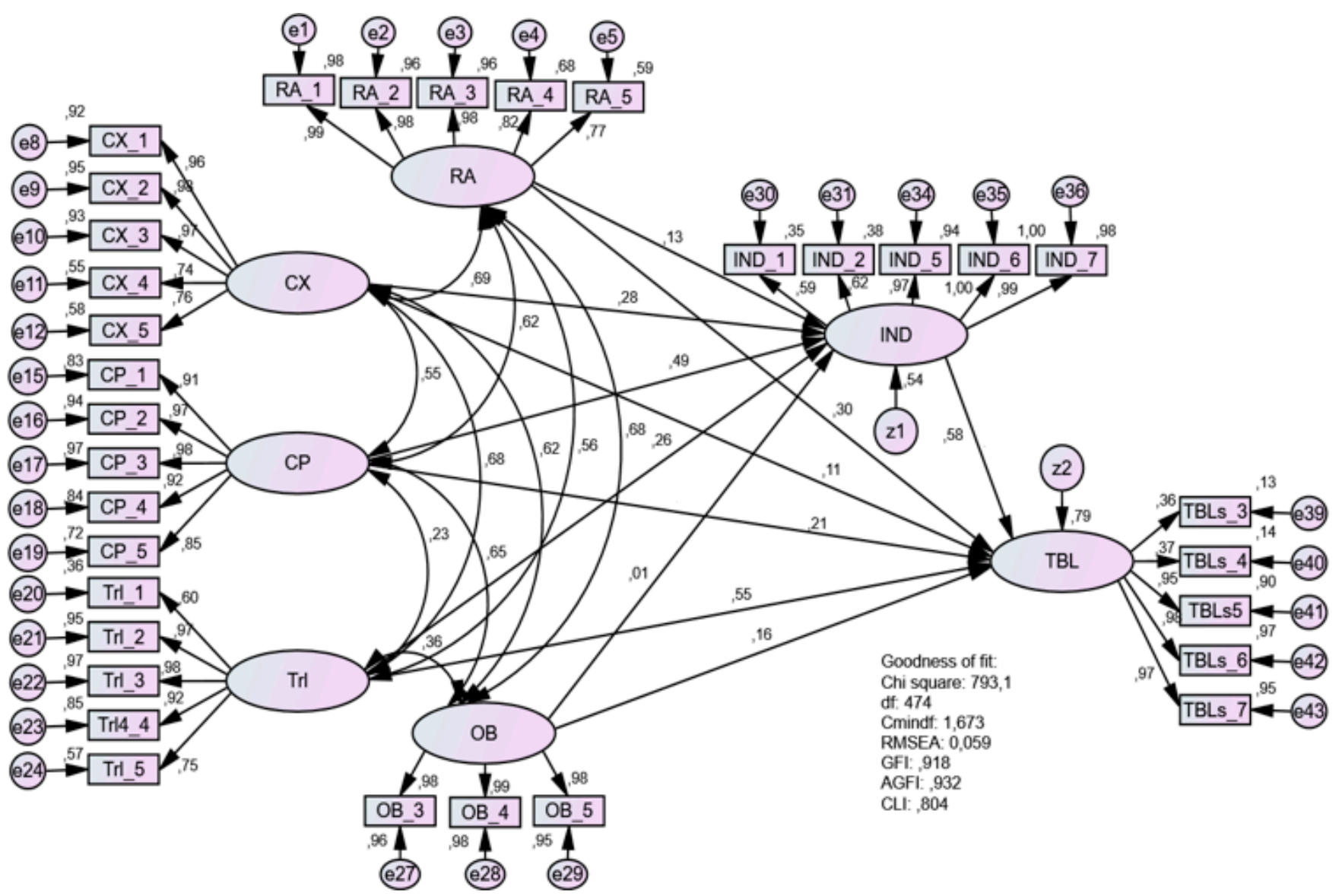

Figure 2. Modified results for the proposed model.

Table 5. Parameter estimation (regression weight) for modified model.

\begin{tabular}{|c|c|c|c|c|c|c|c|}
\hline & & & Estimate & S.E & C.R & $\mathbf{P}$ & Results \\
\hline \multirow{5}{*}{$\begin{array}{c}\text { Effective } \\
\text { implementation of I4.0 }\end{array}$} & $\longleftarrow$ & Relative Advantages & 0.13 & 0.054 & 2.403 & 0.026 & Significant \\
\hline & $\longleftarrow$ & Complexity & 0.28 & 0.053 & 5.261 & $* * * *$ & Significant \\
\hline & 4 & Compatibility & 0.49 & 0.093 & 5.702 & $* * * *$ & Significant \\
\hline & $\leftarrow$ & Trialability & 0.26 & 0.042 & 6.188 & $* * * *$ & Significant \\
\hline & $\longleftarrow$ & Observability & 0.01 & 0.030 & 0.312 & 0.049 & Significant \\
\hline \multirow{5}{*}{$\begin{array}{c}\text { TBL } \\
\text { Sustainability }\end{array}$} & 4 & Relative Advantages & 0.30 & 0.061 & 4.842 & $* * * *$ & Significant \\
\hline & 4 & Complexity & 0.11 & 0.023 & 4.712 & 0.018 & Significant \\
\hline & $\longleftarrow$ & Compatibility & 0.21 & 0.058 & 3.597 & 0.038 & Significant \\
\hline & 4 & Trialability & 0.55 & 0.084 & 6.521 & $* * * *$ & Significant \\
\hline & $\longleftarrow$ & Observability & 0.16 & 0.046 & 3.275 & $* * * *$ & Significant \\
\hline $\begin{array}{c}\text { TBL } \\
\text { Sustainability }\end{array}$ & $\longleftarrow$ & $\begin{array}{c}\text { Effective } \\
\text { implementation of I4.0 }\end{array}$ & 0.58 & 0.084 & 6.912 & $* * * *$ & Significant \\
\hline
\end{tabular}

Note: ${ }^{* * * *}$ is significant symbol.

Most SMEs have adequate infrastructural systems to implement smart technologies. Their employees have the necessary knowledge and understanding of smart technologies so that they do not need a lot of training and have no problem in applying it. Businesses also have the technical support to implement Industry 4.0. Therefore, the perception of low complexity significantly increases the implementation of Industry 4.0 by $28 \%$ (Hypothesis $\mathrm{H} 2 \mathrm{a}$ ) and environmental or sustainability achievement by $11 \%$ (Hypothesis $\mathrm{H} 2 \mathrm{~b}$ ).

Compatibility of the system with the technological conditions of SMEs is the concern of this study. If the smart technology is compatible with the organisation's system, they will easily accept to adopt Industry 4.0. On the other hand, if the company has to make 
various adjustments, like, for example, integrating software, they will be more reluctant to adopt Industry 4.0. This research asked SMEs about the compatibility of smart technology and their willingness to adopt Industry 4,0. The more compatible their systems, the more interested SMEs were in adopting Industry 4.0 (Hypothesis H3a), which in turn makes it easier for them to reach their sustainability goals (Hypothesis $\mathrm{H} 3 \mathrm{~b}$ ).

Due to the limited funds that SMEs have, it is important for them to have the opportunity to try out new technologies before adopting them. Doing this helps them see the performance benefits of the new technology as well as iron out any difficulties that the implementation might encounter. This process makes implementation easier and more cost-effective because it deals with issues before an expensive roll-out [112]. If, after trying the technology, they feel the benefits, then, they will not hesitate to adopt it [114]. This is evident from the estimation results. There is a significant effect of trialability on I4.0 implementation by $26 \%$ (Hypothesis $\mathrm{H} 4 \mathrm{a}$ ). Using smart technologies provides greater control over operational activities because it is easy to recover from mistakes when using smart technologies. If SMEs feel that they can reduce waste in production and reduce error rates, then the sustainability goals will be achieved. This causes trialability to have a high positive and significant effect on sustainability by 55\% (Hypothesis H4b).

SMEs need to evaluate their business performance by comparing it with that of their competitors. By adopting I4.0, they can easily see the business performance of their competitors. Even though the effect is very weak, at only 1\%, it has a significant effect (Hypothesis H5a). Smart technology is able to streamline the process of monitoring business operations, and analysing customer wishes and complaints. These processes can be done easily without consuming a lot of resources. Therefore, observability has a positive effect on sustainability goals, and seems to improve them by $16 \%$ following I4.0 implementation (Hypothesis H5b).

This study also observes the indirect effect of relative advantage, complexity, compatibility, trialability, and observability on sustainability goals through I4.0 implementation as a mediating variable, as shown in Table 6. By using the result of standardised indirect effects, this research shows that the implementation of I4.0 mediates the effect of relative advantage $(\mathrm{H} 1 \mathrm{c})$ by $14.3 \%$, complexity $(\mathrm{H} 2 \mathrm{c})$ by $29 \%$, trialability $(\mathrm{H} 4 \mathrm{c}) 27.7 \%$, and observability (H5c) by $10.2 \%$ on sustainability goals. However, I4.0 implementation cannot mediate perfectly the effect of compatibility on sustainability goals (H3c). For summary of research hypothesis refer Table 7 .

Table 6. Standardized indirect effects.

\begin{tabular}{cccccccc}
\hline & RA & CX & CP & TRL & OB & IND & TBL \\
\hline IND & 0.000 & 0.000 & 0.000 & 0.000 & 0.000 & 0.000 & 0.000 \\
TBL & 0.143 & 0.290 & 0.025 & 0.277 & 0.102 & 0.000 & 0.000 \\
Sig & 0.003 & 0.001 & 0.062 & 0.008 & 0.051 & 0.000 & 0.000 \\
\hline
\end{tabular}

Table 7. Summary of research hypothesis results.

\begin{tabular}{lc}
\multicolumn{1}{c}{ Research Hypotheses } & Results \\
\hline H1a. There is a significant positive relationship between relative advantage and & Supported \\
effective implementation of I4.0. & Supported \\
\hline H1b. There is a significant positive relationship between relative advantage and \\
TBL sustainability. & Supported \\
\hline $\begin{array}{l}\text { H1c. Effective implementation of I4.0 mediates the relationship between the relative } \\
\text { advantage and TBL sustainability. }\end{array}$ & \\
\hline
\end{tabular}


Table 7. Cont.

\begin{tabular}{lc}
\hline \multicolumn{1}{c}{ Research Hypotheses } & Results \\
\hline $\begin{array}{l}\text { H2a. There is a significant positive relationship between complexity and effective } \\
\text { implementation of I4.0. }\end{array}$ & Supported \\
\hline $\begin{array}{l}\text { H2b. There is a significant positive relationship between complexity and TBL } \\
\text { sustainability. }\end{array}$ & Supported \\
\hline $\begin{array}{l}\text { H2c. Industry } 4.0 \text { implementation mediates the relationship between complexity } \\
\text { and TBL sustainability. }\end{array}$ & Supported \\
\hline $\begin{array}{l}\text { H3a. There is a significant positive relationship between compatibility and I4.0 } \\
\text { implementation. }\end{array}$ & Supported \\
\hline $\begin{array}{l}\text { H3b. There is a significant positive relationship between compatibility and TBL } \\
\text { sustainability. }\end{array}$ & Supported \\
\hline $\begin{array}{l}\text { H3c. Industry } 4.0 \text { implementation mediates the relationship between compatibility } \\
\text { and TBL sustainability. }\end{array}$ & Supported \\
\hline $\begin{array}{l}\text { H4a. There is a significant positive relationship between trialability and I4.0 } \\
\text { implementation. }\end{array}$ & Supported \\
\hline $\begin{array}{l}\text { H4b. There is a significant positive relationship between trialability and TBL } \\
\text { sustainability. }\end{array}$ & Supported \\
\hline $\begin{array}{l}\text { H4c. Industry } 4.0 \text { implementation mediates the relationship between trialability and } \\
\text { TBL sustainability. }\end{array}$ & Supported \\
\hline $\begin{array}{l}\text { H5a. There is a significant positive relationship between observability and I4.0 } \\
\text { implementation. }\end{array}$ & Supported \\
\hline $\begin{array}{l}\text { H5b. There is a significant positive relationship between observability and TBL } \\
\text { sustainability. }\end{array}$ & Supported \\
\hline and TBL sustainability. & Supported \\
\hline
\end{tabular}

\section{Discussion}

Social equity, ecological integrity, and financial profitability, known as the triple bottom line or sustainability goals, are important measurements for small and medium enterprises (SMEs) that are often ineffective and inefficient in running their business. The achievement of sustainability goals is not only about environmental performance [7] but also about improving capabilities in serving consumers more efficiently and effectively $[14,18,19]$. To reach their sustainability goals, SMEs should have innovation characteristics, such as relative advantage, complexity, compatibility, trialability, and observability to effectively implement I4.0. These characteristics increase the willingness of SMEs to implement I4.0 and improve their environmental performance [39] Therefore, the aim of this research is to analyse the effect of innovation characteristics on the implementation of I4.0.

The results of the hypothesis test show that relative advantage created a very significant impact on the effective implementation of I4.0. Meanwhile, it has been observed that Chinese companies that adopted RFID technologies without relative advantage could not increase their performance [94]. Most respondents believe that I4.0 implementation results in cost reductions, more efficient use of resources and better monitoring systems, which in turn increases sales and revenues. Companies become more agile businesses able to produce customized products. This research also found that implementation of I4.0 increases sustainability performance by $58 \%$. Even though the investment in technology is quite high, many SMEs believe that the benefits will outweigh the disadvantages, as also stated by reference [97].

Complexity in using smart technologies reduces the likelihood of them being adopted [98]. This research asked respondents whether smart technology is easy to understand and implement, whether SMEs have adequate infrastructural systems and whether employees 
have the required knowledge. The uncomplexity perception in using smart technology has a positive significant effect on I4.0 implementation and sustainability performance.

Compatibility of technology with existing IT is also a main issue when SMEs want to adopt I4.0. Smart technologies should be compatible with the existing values and mentality of the employees in organisations. Similar to other studies, when the new processes fit with the old systems, companies are more likely to implement a new value creation approach [92,112]. So, the findings related to compatibility indicated a significant impact on effective implementation of I4.0. Although giving smaller impact to sustainability goals by $21 \%$, this research found the same result as that of reference [114]. I4.0 technologies have the ability to create harmony with their natural surroundings.

Trialability is an important feature in emerging technologies [107] because it significantly increases the I4.0 implementation rate [118]. This research has an inline result with previous studies. Trialability decreases SMEs' resistance to adopting technology. In addition, trialability can improve sustainability performance because it reduces the possibility of human error when using smart technology.

The ability of technology to track competitors' success was not a major concern for most respondents in this study. This is contrary to previous studies, such as that of reference [120-124], that found a significant relationship between observability and technology implementation. This research is in line with the study conducted by reference $[97,129]$. Malaysian SMEs are more focused on sustainability goals. This is indicated by the influence of observability on sustainability goals, which is greater than on the implementation of I4.0, and this is why the implementation of I4.0 does not fully support the influence of observability on sustainability goals.

\section{Implications of the Study}

Roger's diffusion of innovation model in the research highlighted the significance of the attitude toward Industry 4.0 adoption and implementation intention in terms of attaining the sustainable development goals. This study thus includes several significant implication CEOs, owners and managers of the SMEs. Therefore, the implications of the study are not restricted to Malaysia SMEs only, but may potentially benefit companies operating in other emerging and advanced economies. First of all, the study indicates that the innovation characteristics of Industry 4.0 technologies play a key role in the adoption of Industry 4.0 towards achieving sustainable development goals. Therefore, SMEs managers should do their utmost to foster the technology's characteristics of innovations: the relative advantages of Industry 4.0 to meet the customer requirements in sustainable manners, such as the cost reduction, enhanced energy efficiency, sales and revenue proficiency; introduce Industry 4.0 technologies more flexible and more compatible for quick adoption; reduce the difficulties of Industry 4.0 technologies and make it easy to learn and use for the employees. SMEs can observe and go for a trailable project toward their potential customers as well.

\section{Conclusions, Recommendation, and Limitation}

The technology of innovation theory has been applied to measure effective implementation of I4.0. Not many studies have been conducted in this regard and this study will bring more insights to companies adopting the concept. Prior research ignored the meditation effect of effective implementation of I4.0 and this research has addressed this. This study also makes a contribution by developing a model which has been tested hypothetically and will be a significant study for Malaysian SMEs. Attempts to measure the implications of I4.0 on TBL sustainability has also been done in this research. This research has proven that technology innovations influence positively on effective implementation of Industry 4.0 and sustainability goals. Implementation of I4.0 mediates the relationship between technology innovation and sustainability goals. However, the indirect effect of observability to sustainability is not really significant. This research concludes that the implementation of I4.0 partially supports the relationship between these two variables. Time constraints due to the pandemic were a real challenge. Another limitation is that the only 
social variable considered is the level of awareness about sustainability among employees. The ideal number of respondents should be improved for future studies. Studies can be extended to other industries. More studies can be done in other countries to compare the implementation of I4.0.

Author Contributions: Conceptualization, S.J. and M.N.H.R.; methodology, M.N.H.R. and H.M.; software, H.M.; validation, H.M.; formal analysis, S.J. and H.M.; investigation, M.N.H.R., C.A.N.M., A.K.; resources, Z.H.; writing—original draft preparation, S.J., M.N.H.R. and H.M.; writing—review and editing, S.J. and H.M.; supervision, S.J.; project administration, S.J. and C.A.N.M. All authors have read and agreed to the published version of the manuscript.

Funding: This research was funded by the Ministry of Higher Education, Malaysia Under the FRGS grant (FRGS/1/2018/SS01/MMU/02/6) and the Article Processing Charge was funded from the grant.

Institutional Review Board Statement: Not applicable.

Informed Consent Statement: Not applicable.

Data Availability Statement: Not applicable.

Acknowledgments: We wish to thank the Ministry of Higher Education Malaysia for the opportunity and Multimedia University for all the support extended.

Conflicts of Interest: The authors declare no conflict of interest.

\section{References}

1. Elkington, J. Towards the sustainable corporation: Win-win-win business strategies for sustainable development. Calif. Manag. Rev. 1994, 36, 90-100. [CrossRef]

2. Ramanathan, R.; He, Q.; Black, A.; Ghobadian, A.; Gallear, D. Environmental regulations, innovation and firm performance: A revisit of the Porter hypotheses. J. Clean. Prod. 2017, 155, 79-92. [CrossRef]

3. Jayashree, S.; Reza, M.N.H.; Mohiuddin, M. Impact of Cleaner Production and Environmental Management Systems on Sustainability: The Moderating Role of Industry 4.0. In IOP Conference Series: Earth and Environmental Science; IOP Publishing: Bristol, UK, 2021; Volume 795, p. 012013. [CrossRef]

4. Horng, J.S.; Liu, C.H.; Chou, S.F.; Tsai, C.Y.; Chung, Y.C. From innovation to sustainability: Sustainability innovations of eco-friendly hotels in Taiwan. Int. J. Hosp. Manag. 2017, 63, 44-52. [CrossRef]

5. Rauter, R.; Globocnik, D.; Perl-Vorbach, E.; Baumgartner, R.J. Open innovation and its effects on economic and sustainability innovation performance. J. Innov. Knowl. 2019, 4, 226-233. [CrossRef]

6. Deng-Westphal, M.; Beeton, S.; Anderson, A. 15 The paradox of adopting tourism ecolabels. In The Practice of Sustainable Tourism: Resolving the Paradox; Routledge: London, UK, 2015; Volume 228.

7. Díaz-Chao, Á.; Ficapal-Cusí, P.; Torrent-Sellens, J. Environmental assets, industry 4.0 technologies and firm performance in Spain: A dynamic capabilities path to reward sustainability. J. Clean. Prod. 2021, 281, 125264. [CrossRef]

8. Miao, C.; Fang, D.; Sun, L.; Luo, Q. Natural resources utilization efficiency under the influence of green technological innovation. Resour. Conserv. Recycl. 2017, 126, 153-161. [CrossRef]

9. Ali Qalati, S.; Li, W.; Ahmed, N.; Ali Mirani, M.; Khan, A. Examining the Factors Affecting SME Performance: The Mediating Role of Social Media Adoption. Sustainability 2021, 13, 75. [CrossRef]

10. Haseeb, M.; Hussain, H.I.; Ślusarczyk, B.; Jermsittiparsert, K. Industry 4.0: A solution towards technology challenges of sustainable business performance. Soc. Sci. 2019, 8, 154. [CrossRef]

11. Bocconcelli, R.; Cioppi, M.; Pagano, A. Social media as a resource in SMEs' sales process. J. Bus. Ind. Mark. 2017, 23, 693-709. [CrossRef]

12. Dias Canedo, E.; Morais do Vale, A.P.; Patrão, R.L.; Camargo de Souza, L.; Machado Gravina, R.; Eloy dos Reis, V.; Lúcio Lopes Mendonça, F.; de Sousa, R.T. Information and Communication Technology (ICT) Governance Processes: A Case Study. Information 2020, 11, 462. [CrossRef]

13. Lutfi, A. Investigating the Moderating Role of Environmental Uncertainty between Institutional Pressures and ERP Adoption in Jordanian SMEs. J. Open Innov. Technol. Mark. Complex. 2020, 6, 91. [CrossRef]

14. Brozzi, R.; Forti, D.; Rauch, E.; Matt, D.T. The Advantages of Industry 4.0 Applications for Sustainability: Results from a Sample of Manufacturing Companies. Sustainability 2020, 12, 3647. [CrossRef]

15. Andulkar, M.; Le, D.T.; Berger, U. A multi-case study on Industry 4.0 for SMEs in Brandenburg, Germany. In Proceedings of the 51st Hawaii International Conference on System Sciences, Hilton Waikoloa Village, HI, USA, 3-6 January 2018.

16. Raj, A.; Dwivedi, G.; Sharma, A.; de Sousa Jabbour, A.B.L.; Rajak, S. Barriers to the adoption of industry 4.0 technologies in the manufacturing sector: An inter-country comparative perspective. Int. J. Prod. Econ. 2020, 224, 107546. [CrossRef] 
17. Jayashree, S.; Malarvizhi, C.A.; Reza, M.N.H. The Challenges and Opportunities of Industry 4.0-A Review. Asia Proc. Soc. Sci. 2020, 5, 173-178. [CrossRef]

18. Dean, M.; Spoehr, J. The fourth industrial revolution and the future of manufacturing work in Australia: Challenges and opportunities. Labour Ind. A J. Soc. Econ. Relat. Work. 2018, 28, 166-181. [CrossRef]

19. Santos, K.; Loures, E.; Piechnicki, F.; Canciglieri, O. Opportunities assessment of product development process in Industry 4.0. Procedia Manuf. 2017, 11, 1358-1365. [CrossRef]

20. Roblek, V.; Meško, M.; Krapež, A. A complex view of industry 4.0. Sage Open 2016, 6, 2158244016653987. [CrossRef]

21. Guillermo, R.-A.; Bribiesca-Correa, G. Assessing Digital Transformation in Universities. Future Internet 2021, 13, 52.

22. Stentoft, J.; Wickstrøm, K.A.; Philipsen, K.; Haug, A. Drivers and Barriers for Industry 4.0 Readiness and Practice: Empirical Evidence from Small and Medium-Sized Manufacturers. Prod. Plan. Control 2021, 32, 811-828. [CrossRef]

23. Saunders, M.; Tosey, P. The Layers of Research Design. Rapp. Mag. NLP Prof. 2012, 4, 58-59.

24. Ghobakhloo, M. The future of manufacturing industry: A strategic roadmap toward Industry 4.0. J. Manuf. Technol. Manag. 2018, 29, 910-936. [CrossRef]

25. Machado, C.G.; Winroth, M.P.; Ribeiro da Silva, E.H.D. Sustainable manufacturing in Industry 4.0: An emerging research agenda. Int. J. Prod. Res. 2020, 58, 1462-1484. [CrossRef]

26. Stock, T.; Seliger, G. Opportunities of sustainable manufacturing in industry 4.0. Procedia Cirp 2016, 40, 536-541. [CrossRef]

27. Kiel, D.; Müller, J.; Arnold, C.; Voigt, K.I. Sustainable industrial value creation: Benefits and challenges of Industry 4.0. In Proceedings of the ISPIM Innovation Symposium, The International Society for Professional Innovation Management (ISPIM), Vienna, Austria, 18-21 June 2017.

28. Ender, J.; Wagner, J.C.; Kunert, G.; Guo, F.B.; Larek, R.; Pawletta, T. Concept of a self-learning workplace cell for worker assistance while collaboration with a robot within the self-adapting-production-planning-system. Inform. Automa. Pomiary Gospod. Ochr. Śr. 2019, 9, 4-9. [CrossRef]

29. Frank, A.G.; Dalenogare, L.S.; Ayala, N.F. Industry 4.0 technologies: Implementation patterns in manufacturing companies. Int. J. Prod. Econ. 2019, 210, 15-26. [CrossRef]

30. Castellacci, F. Technological paradigms, regimes and trajectories: Manufacturing and service industries in a new taxonomy of sectoral patterns of innovation. Res. Policy 2008, 37, 978-994. [CrossRef]

31. Frank, A.G.; Cortimiglia, M.N.; Ribeiro, J.L.D.; de Oliveira, L.S. The effect of innovation activities on innovation outputs in the Brazilian industry: Market-orientation vs. technology-acquisition strategies. Res. Policy. 2016, 45, 577-592.

32. Gandomi, A.; Haider, M. Beyond the hype: Big data concepts, methods, and analytics. Int. J. Inf. Manag. 2015, 35, 137-144. [CrossRef]

33. Torres, R.; Sidorova, A.; Jones, M.C. Enabling firm performance through business intelligence and analytics: A dynamic capabilities perspective. Inf. Manag. 2018, 55, 822-839. [CrossRef]

34. Sharma, R.; Mithas, S.; Kankanhalli, A. Transforming decision-making processes: A research agenda for understanding the impact of business analytics on organizations. Eur. J. Inf. Syst. 2014, 23, 433-441. [CrossRef]

35. Beier, G.; Niehoff, S.; Ziems, T.; Xue, B. Sustainability aspects of a digitalized industry-A comparative study from China and Germany. Int. J. Precis. Eng. Manuf.-Green Technol. 2017, 4, 227-234. [CrossRef]

36. Hofmann, E.; Rüsch, M. Industry 4.0 and the current status as well as future prospects on logistics. Comput. Ind. 2017, 89, 23-34. [CrossRef]

37. Gillani, F.; Chatha, K.A.; Jajja, M.S.S.; Farooq, S. Implementation of digital manufacturing technologies: Antecedents and consequences. Int. J. Prod. Econ. 2020, 229, 107748. [CrossRef]

38. Oláh, J.; Aburumman, N.; Popp, J.; Khan, M.A.; Haddad, H.; Kitukutha, N. Impact of Industry 4.0 on Environmental Sustainability. Sustainability 2020, 12, 4674. [CrossRef]

39. Ozusaglam, S.; Kesidou, E.; Wong, C.Y. Performance effects of complementarity between environmental management systems and environmental technologies. Int. J. Prod. Econ. 2018, 197, 112-122. [CrossRef]

40. Arda, O.A.; Bayraktar, E.; Tatoglu, E. How do integrated quality and environmental management practices affect firm performance? Mediating roles of quality performance and environmental proactivity. Bus. Strategy Environ. 2019, $28,64-78$. [CrossRef]

41. Girod, S.J.; Whittington, R. Reconfiguration, restructuring and firm performance: Dynamic capabilities and environmental dynamism. Strateg. Manag. J. 2017, 38, 1121-1133. [CrossRef]

42. Singh, S.K.; Del Giudice, M.; Chierici, R.; Graziano, D. Green innovation and environmental performance: The role of green transformational leadership and green human resource management. Technol. Forecast. Soc. Chang. 2020, 150, 119762. [CrossRef]

43. Furstenau, L.B.; Sott, M.K.; Kipper, L.M.; Machado, Ê.L.; Lopez-Robles, J.R.; Dohan, M.S.; Cobo, M.J.; Zahid, A.; Abbasi, Q.H.; Imran, M.A. Link Between Sustainability and Industry 4.0: Trends, Challenges and New Perspectives. IEEE Access 2020, 8 , 140079-140096. [CrossRef]

44. Vaidya, S.; Ambad, P.; Bhosle, S. Industry 4.0-a glimpse. Procedia Manuf. 2018, 20, 233-238. [CrossRef]

45. Xu, L.D.; Xu, E.L.; Li, L. Industry 4.0: State of the art and future trends. Int. J. Prod. Res. 2018, 56, 2941-2962. [CrossRef]

46. Zhong, R.Y.; Xu, X.; Klotz, E.; Newman, S.T. Intelligent manufacturing in the context of industry 4.0: A review. Engineering 2017, 3, 616-630. [CrossRef] 
47. Arbix, G.; Salerno, M.; Zancul, E.; Amaral, G.; Lins, L. Advanced manufacturing: What is to be learnt from Germany, the US, and China. Novos. Estud. CEBRAP 2017, 36, 29-49. [CrossRef]

48. Bernat, S.; Karabag, S.F. Strategic alignment of technology: Organising for technology upgrading in emerging economy firms. Technol. Forecast. Soc. Chang. 2019, 145, 295-306. [CrossRef]

49. Phillips, L.A.; Calantone, R.; Lee, M.T. International technology adoption: Behavior structure, demand certainty and culture. J. Bus. Ind. Mark. 1994, 9, 16-28. [CrossRef]

50. Eaton, J.; Kortum, S. International technology diffusion: Theory and measurement. Int. Econ. Rev. 1999, 40, 537-570. [CrossRef]

51. Comin, D.; Hobijn, B. Cross-country technology adoption: Making the theories face the facts. J. Monet. Econ. 2004, 51, 39-83. [CrossRef]

52. Parente, S.L.; Prescott, E.C. Barriers to technology adoption and development. J. Political Econ. 1994, 102, 298-321. [CrossRef]

53. Robertson, T.S.; Gatignon, H. Competitive effects on technology diffusion. J. Mark. 1986, 50, 1-12. [CrossRef]

54. Alekseev, A.N.; Evdokimov, S.Y.; Tarasova, A.Y.; Khachaturyan, K.S.; Khachaturyan, A.A. Financial strategy of development of industry 4.0 in the countries with developing economy. Rev. Espac. 2018, 39, 1.

55. Luthra, S.; Mangla, S.K. Evaluating challenges to Industry 4.0 initiatives for supply chain sustainability in emerging economies. Process Saf. Environ. Prot. 2018, 117, 168-179. [CrossRef]

56. Kagermann, H. Change through digitization-Value creation in the age of Industry 4.0. In Management of Permanent Change; Springer: Gabler, Germany, 2015; pp. 23-45.

57. Davis, F.D. Perceived usefulness, perceived ease of use, and user acceptance of information technology. MIS Q. 1989, 13, 319-340. [CrossRef]

58. Davis, F.D.; Bagozzi, R.P.; Warshaw, P.R. Extrinsic and intrinsic motivation to use computers in the workplace 1. J. Appl. Soc. Psychol. 1992, 22, 1111-1132. [CrossRef]

59. Ajzen, I. From intentions to actions: A theory of planned behavior. In Action Control; Springer: Berlin/Heidelberg, Germany, 1985; pp. 11-39.

60. Rogers, E.M. Diffusion of Innovations; Simon and Schuster: New York, NY, USA, 2010.

61. Tornatzky, L.G.; Fleischer, M.; Chakrabarti, A.K. Processes of Technological Innovation; Lexington Books: Lanham, MD, USA, 1990.

62. Compeau, D.R.; Higgins, C.A. Computer self-efficacy: Development of a measure and initial test. MIS Q. 1995, 19, 189-211. [CrossRef]

63. Rogers, E.M. Diffusion of Innovations, 5th ed.; Free Press: New York, NY, USA, 2003.

64. Schienstock, G. Path dependency and path creation: Continuity vs. fundamental change in national economies. J. Futures Stud. 2011, 15, 63-76.

65. Gajdzik, B.; Grabowska, S.; Sebastian, S. A Theoretical Framework for Industry 4.0 and Its Implementation with Selected Practical Schedules. Energies 2021, 14, 940. [CrossRef]

66. Sudolska, A.; Łapińska, J. Exploring Determinants of Innovation Capability in Manufacturing Companies Operating in Poland. Sustainability 2020, 12, 7101. [CrossRef]

67. Cyfert, S.; Glabiszewski, W.; Zastempowski, M. Impact of Management Tools Supporting Industry 4.0 on the Importance of CSR during COVID-19. Gener. Z. Energ. 2021, 14, 1642. [CrossRef]

68. Kuś, A.; Pypłacz, P. The Importance of Information Management in the Context of Industry 4.0: Evidence from the KuyavianPomeranian Forbes Diamonds. Soc. Sci. 2019, 8, 169. [CrossRef]

69. Dorota, G.P.; Agnieszka, K. Determinants of Innovation Activities in Small Enterprises: A Model Approach. Eur. Res. Stud. J. 2020, XXIII, 137-148. [CrossRef]

70. Maciej, Z.; Waldemar, G.; Krzysztof, K.; Szymon, C. Technological Innovation Capabilities of Small and Medium-Sized Enterprises. Eur. Res. Stud. J. 2020, XXIII, 460-474. [CrossRef]

71. Brettel, M.; Friedrichsen, N.; Keller, M.; Rosenberg, M. How virtualization, decentralization and network building change the manufacturing landscape. An Industry 4.0 Perspective. Periodical 2014, 8, 37.

72. Vrchota, J.; Volek, T.; Novotná, M. Factors Introducing Industry 4.0 to SMES. Soc. Sci. 2019, 8, 130. [CrossRef]

73. Moeuf, A.; Lamouri, S.; Pellerin, R.; Tamayo-Giraldo, S.; Tobon-Valencia, E.; Eburdy, R. Identification of critical success factors, risks and opportunities of Industry 4.0 in SMEs. Int. J. Prod. Res. 2020, 58, 1384-1400. [CrossRef]

74. Lee, J.; Bagheri, B.; Kao, H. Research Letters: A Cyber-Physical Systems architecture for Industry 4.0-based manufacturing systems. Manuf. Lett. 2015, 3, 18-23. [CrossRef]

75. Deloitte-Industry 4.0. The Industry 4.0 Paradox. Overcoming Disconnects on the Path to Digital Transformation, Deloitte Insights, 2018 Deloitte Development LLC. Available online: https://www2.deloitte.com/content/dam/Deloitte/cn/ Documents/energy-resources/deloitte-cn-er-industry-4.0-paradox-overcoming-disconnects-en-full-report-190225.pdf (accessed on 9 September 2020).

76. PwC-Global Industry 4.0 Survey. What We Mean by Industry 4.0/Survey Key Findings/Blueprint for Digital Success, PwC 2016. Available online: https://www.pwc.com/gx/en/industries/industries-4.0/landing-page/industry-4.0-building-yourdigitalenterprise-april-2016.pdf (accessed on 20 August 2020).

77. Yu, F.; Schweisfurth, T. Industry 4.0 technology implementation in SMEs-A survey in the Danish-German border region. Int. J. Innov. Stud. 2020, 4, 76-84. [CrossRef] 
78. Li, G.; Hou, Y.; Wu, A. Fourth industrial revolution: Technological drivers, impacts and coping methods. Chin. Geogr. Sci. 2017, 27, 626-637. [CrossRef]

79. Russman, M.; Lorenz, M.; Gerbert, P.; Waldner, M.; Justus, J.; Engel, P.; Harnisch, M. Industry 4.0 the future of productivity and growth in Manufacturing Industries. Boston Consult. 2015. [CrossRef]

80. de Soto, B.G.; Agustí-Juan, I.; Hunhevicz, J.; Joss, S.; Graser, K.; Habert, G.; Adey, B.T. Productivity of digital fabrication in construction: Cost and time analysis of a robotically built wall. Autom. Constr. 2018, 92, 297-311. [CrossRef]

81. de Sousa Jabbour, A.B.L.; Jabbour, C.J.C.; Foropon, C.; Godinho Filho, M. When titans meet-Can industry 4.0 revolutionise the environmentally-sustainable manufacturing wave? The role of critical success factors. Technol. Forecast. Soc. Chang. 2018, 132, 18-25. [CrossRef]

82. Ford, S.; Despeisse, M. Additive manufacturing and sustainability: An exploratory study of the advantages and challenges. J. Clean. Prod. 2016, 137, 1573-1587. [CrossRef]

83. Müller, E.; Hopf, H. Competence center for the digital transformation in small and medium-sized enterprises. Procedia Manuf. 2017, 11, 1495-1500. [CrossRef]

84. Bai, C.; Dallasega, P.; Orzes, G.; Sarkis, J. Industry 4.0 technologies assessment: A sustainability perspective. Int. J. Prod. Econ. 2020, 229, 107776. [CrossRef]

85. Bag, S.; Gupta, S.; Kumar, S. Industry 4.0 adoption and 10R advance manufacturing capabilities for sustainable development. Int. J. Prod. Econ. 2021, 231, 107844. [CrossRef]

86. Burritt, R.; Christ, K. Industry 4.0 and environmental accounting: A new revolution? Asian J. Sustain. Soc. Responsib. 2016, 1, 23-38. [CrossRef]

87. Moore, G.C.; Benbasat, I. Development of an instrument to measure the perceptions of adopting an information technology innovation. Inf. Syst. Res. 1991, 2, 192-222. [CrossRef]

88. Amini, M.; Bakri, A. Cloud Computing Adoption by SMEs in Malaysia: A Multi-Perspective Framework based on DOI Theory and TOE Framework. J. Inf. Technol. Inf. Syst. Res. 2015, 9, 121-135.

89. Oettmeier, K.; Hofmann, E. Additive manufacturing technology adoption: An empirical analysis of general and supply chainrelated determinants. J. Bus. Econ. 2017, 87, 97-124. [CrossRef]

90. Al Mamun, A. Diffusion of innovation among Malaysian manufacturing SMEs. Eur. J. Innov. Manag. 2018, 21, 113-141. [CrossRef]

91. Alkhalil, A.; Sahandi, R.; John, D. An exploration of the determinants for decision to migrate existing resources to cloud computing using an integrated TOE-DOI model. J. Cloud Comput. 2017, 6, 1-20. [CrossRef]

92. Arnold, C.; Veile, J.; Voigt, K.I. What drives industry 4.0 adoption? An examination of technological, organizational, and environmental determinants. In Proceedings of the International Association for Management of Technology (IAMOT) Conference, Birmingham, UK, 22-26 April 2018.

93. Feroz, A.K.; Zo, H.; Chiravuri, A. Digital transformation and environmental sustainability: A review and research agenda. Sustainability 2021, 13, 1530. [CrossRef]

94. Wei, J.; Lowry, P.B.; Seedorf, S. The assimilation of RFID technology by Chinese companies: A technology diffusion perspective. Inf. Manag. 2015, 52, 628-642. [CrossRef]

95. Sun, S.; Cegielski, C.G.; Jia, L.; Hall, D.J. Understanding the factors affecting the organizational adoption of big data. J. Comput. Inf. Syst. 2018, 58, 193-203. [CrossRef]

96. Dubey, R.; Gunasekaran, A.; Childe, S.J.; Papadopoulos, T.; Luo, Z.; Wamba, S.F.; Roubaud, D. Can big data and predictive analytics improve social and environmental sustainability? Technol. Forecast. Soc. Chang. 2019, 144, 534-545. [CrossRef]

97. Seles, B.M.R.P.; de Sousa Jabbour, A.B.L.; Jabbour, C.J.C.; de Camargo Fiorini, P.; Mohd-Yusoff, Y.; Thomé, A.M.T. Business opportunities and challenges as the two sides of the climate change: Corporate responses and potential implications for big data management towards a low carbon society. J. Clean. Prod. 2018, 189, 763-774. [CrossRef]

98. Premkumar, G.; Roberts, M. Adoption of new information technologies in rural small businesses. Omega 1999, $27,467-484$. [CrossRef]

99. Ministry of International Trade and Industry (MITI). Industry4WRD: National Policy on Industry 4.0. 2018. Available online: https: //www.miti.gov.my/miti/resources/NationalPolicyonIndustry4.0/Industry4WRD_Final.pdf (accessed on 21 September 2019).

100. Prause, M. Challenges of industry 4.0 technology adoption for SMEs: The case of Japan. Sustainability 2019, 11, 5807. [CrossRef]

101. Slade, E.L.; Dwivedi, Y.K.; Piercy, N.C.; Williams, M.D. Modeling consumers' adoption intentions of remote mobile payments in the United Kingdom: Extending UTAUT with innovativeness, risk, and trust. Psychol. Mark. 2015, 32, 860-873. [CrossRef]

102. Alalwan, A.A.; Dwivedi, Y.K.; Rana, N.P. Factors influencing adoption of mobile banking by Jordanian bank customers: Extending UTAUT2 with trust. Int. J. Inf. Manag. 2017, 37, 99-110. [CrossRef]

103. Dwivedi, Y.K.; Rana, N.P.; Janssen, M.; Lal, B.; Williams, M.D.; Clement, M. An empirical validation of a unified model of electronic government adoption (UMEGA). Gov. Inf. Q. 2017, 34, 211-230. [CrossRef]

104. Dwivedi, Y.K.; Rana, N.P.; Jeyaraj, A.; Clement, M.; Williams, M.D. Re-examining the unified theory of acceptance and use of technology (UTAUT): Towards a revised theoretical model. Inf. Syst. Front. 2019, 21, 719-734. [CrossRef]

105. Wong, L.W.; Leong, L.Y.; Hew, J.J.; Tan, G.W.H.; Ooi, K.B. Time to seize the digital evolution: Adoption of blockchain in operations and supply chain management among Malaysian SMEs. Int. J. Inf. Manag. 2020, 52, 101997. [CrossRef]

106. Saberi, S.; Kouhizadeh, M.; Sarkis, J.; Shen, L. Blockchain technology and its relationships to sustainable supply chain management. Int. J. Prod. Res. 2019, 57, 2117-2135. [CrossRef] 
107. Rana, N.P.; Dwivedi, Y.K.; Williams, M.D.; Weerakkody, V. Adoption of online public grievance redressal system in India: Toward developing a unified view. Comput. Hum. Behav. 2016, 59, 265-282. [CrossRef]

108. Shi, P.; Yan, B. Factors affecting RFID adoption in the agricultural product distribution industry: Empirical evidence from China. SpringerPlus 2016, 5, 1-11. [CrossRef] [PubMed]

109. Cooper, R.B.; Zmud, R.W. Information technology implementation research: A technological diffusion approach. Manag. Sci. 1990, 36, 123-139. [CrossRef]

110. Duckworth, R. Examining Relationships between Perceived Characteristics of Innovation and Adoption Intentions of Small and Medium Enterprises; Northcentral University: Scottsdale, AZ, USA, 2014.

111. Sherehiy, B.; Karwowski, W.; Layer, J.K. A Review of Enterprise Agility: Concepts, Frameworks, and Attributes. Int. J. Ind. Ergon. 2007, 37, 445-460. [CrossRef]

112. Kurnia, S.; Choudrie, J.; Mahbubur, R.M.; Alzougool, B. E-commerce technology adoption: A Malaysian grocery SME retail sector study. J. Bus. Res. 2015, 68, 1906-1918. [CrossRef]

113. Usman, U.M.Z.; Ahmad, M.N.; Zakaria, N.H. The Determinants of Adoption of Cloud-Based ERP of Nigerian's SMES Manufacturing Sector Using Toe Framework and Doi Theory. Int. J. Enterp. Inf. Syst. 2019, 15, 27-43. [CrossRef]

114. Singh, R.; Kumar, S. (Eds.) Green Technologies and Environmental Sustainability; Springer: Berlin/Heidelberg, Germany, 2017.

115. Weiss, J.A.; Dale, B.C. Diffusing against mature technology: Issues and strategy. Ind. Mark. Manag. 1998, 27, 293-304. [CrossRef]

116. Maroufkhani, P.; Tseng, M.L.; Iranmanesh, M.; Ismail, W.K.W.; Khalid, H. Big data analytics adoption: Determinants and performances among small to medium-sized enterprises. Int. J. Inf. Manag. 2020, 54, 102190. [CrossRef]

117. Chau, N.T.; Deng, H.; Tay, R. Critical determinants for mobile commerce adoption in Vietnamese small and medium-sized enterprises. J. Mark. Manag. 2020, 36, 456-487. [CrossRef]

118. Wu, R.; Corbett, J. "Insights into Customer Adoption" in: Innovation in the Electricity Industry: Focus on Distributed Renewable Electricity Generation; Université Laval: Quebec, QC, Canada, 2019; Volume 1, pp. 1-8.

119. Al-Ghatani, S.S. Computer technology adoption in Saudi Arabia: Correlates of perceived innovation attributes. Inf. Technol. Dev. 2003, 10, 57-69. [CrossRef]

120. Asare, A.K.; Brashear-Alejandro, T.G.; Kang, J. B2B technology adoption in customer driven supply chains. J. Bus. Ind. Mark. 2016, 31, 1-12. [CrossRef]

121. Subramanian, G.; Patil, B.T.; Gardas, B.B. Evaluation of enablers of cloud technology to boost industry 4.0 adoption in the manufacturing micro, small and medium enterprises. J. Model. Manag. 2021, 16, 944-962. [CrossRef]

122. Yadegaridehkordi, E.; Hourmand, M.; Nilashi, M.; Shuib, L.; Ahani, A.; Ibrahim, O. Influence of big data adoption on manufacturing companies' performance: An integrated DEMATEL-ANFIS approach. Technol. Forecast. Soc. Chang. 2018, 137, 199-210. [CrossRef]

123. Schniederjans, D.G. Adoption of 3D-printing technologies in manufacturing: A survey analysis. Int. J. Prod. Econ. 2017, 183, 287-298. [CrossRef]

124. Baig, M.I.; Shuib, L.; Yadegaridehkordi, E. Big data adoption: State of the art and research challenges. Inf. Process. Manag. 2019, 56, 102095. [CrossRef]

125. Kapoor, K.K.; Dwivedi, Y.K.; Williams, M.D. Rogers' innovation adoption attributes: A systematic review and synthesis of existing research. Inf. Syst. Manag. 2014, 31, 74-91. [CrossRef]

126. Siew, E.G.; Rosli, K.; Yeow, P.H. Organizational and environmental influences in the adoption of computer-assisted audit tools and techniques (CAATTs) by audit firms in Malaysia. Int. J. Account. Inf. Syst. 2020, 36, 100445. [CrossRef]

127. Bakar, A.R.; Ahmad, S.Z.; Ahmad, N. SME social media use: A study of predictive factors in the United Arab Emirates. Glob. Bus. Organ. Excell. 2019, 38, 53-68. [CrossRef]

128. Ochieng, G.F. The Adoption of Big Data Analytics by Supermarkets in Kisumu County. Ph.D. Thesis, University of Nairobi, Nairobi, Kenya, 2015.

129. Ramdani, B.; Kawalek, P. SME adoption of enterprise systems in the Northwest of England. In Proceedings of the IFIP International Working Conference on Organizational Dynamics of Technology-Based Innovation, Manchester, UK, 14-16 June 2007; Springer: Boston, MA, USA, 2007; pp. 409-429.

130. Saniuk, S.; Saniuk, A.; Cagáňová, D. Cyber Industry Networks as an environment of the Industry 4.0 implementation. Wirel. Netw. 2021, 27, 1649-1655. [CrossRef]

131. Thoben, K.D.; Wiesner, S.; Wuest, T. "Industry 4.0" and smart manufacturing: A review of research issues and application examples. Int. J. Autom. Technol. 2017, 11, 4-16. [CrossRef]

132. Oks, S.J.; Fritzsche, A.; Möslein, K.M. An application map for industrial cyber-physical systems. In Industrial Internet of Things: Cybermanufacturing Systems; Jeschke, S., Brecher, C., Song, H., Rawat, D.B., Eds.; Springer: Cham, Switzerland, 2017; pp. 21-46.

133. Erol, S.; Jäger, A.; Hold, P.; Ott, K.; Sihn, W. Tangible Industry 4.0: A scenario-based approach to learning for the future of production. In Proceedings of the 6th CIRP Conference on Learning Factories, Gjovik, Norway, 29-30 June 2016.

134. Sony, M.; Naik, S. Key ingredients for evaluating Industry 4.0 readiness for organizations: A literature review. Benchmark. Int. J. 2019, 27, 2213-2232. [CrossRef]

135. Wang, S.; Wan, J.; Li, D.; Zhang, C. Implementing smart factory of industrie 4.0: An outlook. Int. J. Distrib. Sens. Netw. 2016, 12, 3159805. [CrossRef]

136. Sony, M.; Naik, S.S. Ten lessons for managers while implementing Industry 4.0. IEEE Eng. Manag. Rev. 2019, 47, 45-52. [CrossRef] 
137. Sony, M.; Naik, S. Industry 4.0 integration with socio-technical systems theory: A systematic review and proposed theoretical model. Technol. Soc. 2020, 61, 101248. [CrossRef]

138. Foidl, H.; Felderer, M. Research challenges of industry 4.0 for quality management. In Proceedings of the International Conference on Enterprise Resource Planning Systems, Munich, Germany, 16-17 November 2015; Springer: Cham, Switzerland, 2015; pp. 121-137.

139. Jayashree, S.; Reza, M.N.H.; Malarvizhi, C.A.N.; Mohiuddin, M. Industry 4.0 implementation and Triple Bottom Line sustainability: An empirical study on small and medium manufacturing firms. Heliyon 2021, 7, e07753. [CrossRef]

140. Hassan, H.; Tretiakov, A.; Whiddett, D. Factors affecting the breadth and depth of e-procurement use in small and medium enterprises. J. Organ. Comput. Electron. Commer. 2017, 27, 304-324. [CrossRef]

141. Hair, J.F., Jr.; Hult, G.T.M.; Ringle, C.M.; Sarstedt, M. A Primer on Partial Least Squares Structural Equation Modeling (PLS-SEM); Sage Publications: Thousand Oaks, CA, USA, 2021.

142. Martins, C.B.M.J.; Steil, A.V.; Todesco, J.L. Factors influencing the adoption of the Internet as a teaching tool at foreign language schools. Comput. Educ. 2004, 42, 353-374. [CrossRef]

143. Pérez-Lara, M.; Saucedo-Martínez, J.A.; Marmolejo-Saucedo, J.A.; Salais-Fierro, T.A.; Vasant, P. Vertical and horizontal integration systems in Industry 4.0. Wirel. Netw. 2020, 26, 4767-4775. [CrossRef]

144. Yong, J.Y.; Yusliza, M.Y.; Ramayah, T.; Chiappetta Jabbour, C.J.; Sehnem, S.; Mani, V. Pathways towards sustainability in manufacturing organizations: Empirical evidence on the role of green human resource management. Bus. Strategy Environ. 2020, 29, 212-228. [CrossRef]

145. Haseeb, M.; Hussain, H.I.; Kot, S.; Androniceanu, A.; Jermsittiparsert, K. Role of social and technological challenges in achieving a sustainable competitive advantage and sustainable business performance. Sustainability 2019, 11, 3811. [CrossRef]

146. Zhu, Q.; Sarkis, J.; Lai, K.-H. Confirmation of a measurement model for green supply chain management practices implementation. Int. J. Prod. Econ. 2008, 111, 261-273. [CrossRef]

147. Teo, T.S.H.; Pian, Y. A contingency perspective on Internet adoption and competitive advantage. Eur. J. Inf. Syst. 2003, 12, 78-92. [CrossRef]

148. Hair, J.F., Jr.; Black, W.C.; Babin, B.J.; Anderson, R.E.; Tatham, L.R. Multivariant Data Analysis; Pearson: Hoboken, NJ, USA, 2006.

149. Maheswari, H. Quality leadership and role to the employee's performance in improving students' satisfaction. In Proceedings of the International Seminar and Call for Papers-Strategic Leadership: Green Management, Jakarta, Indonesia, 12 March 2012.

150. Maheswari, H.; Yudoko, G.; Adhiutama, A. Customer Value Chain Analysis for Sustainable Reverse Logistics Implementation: Indonesian Mobile Phone Industry. In Proceedings of the 2018 IEEE International Conference on Industrial Engineering and Engineering Management (IEEM), Bangkok, Thailand, 16-19 December 2018; pp. 89-92. [CrossRef]

151. Newman, W.L. Social Research Methods: Qualitative and Quantitative Approaches. Teach. Sociol. 2020, 30. [CrossRef]

152. Harwani, Y.; Maheswari, H. Evaluation of operating public service performance in fulfillment community expectation in Jakarta. Mediterr. J. Soc. Sci. 2015, 6, 258-266. [CrossRef] 